\title{
A literature review and categorisation of sustainability- aimed urban metabolism indicators: a context, indicator, mechanism, outcome analysis
}

Yan Song Urban metabolism has been advanced as an

Delft University of Technology

Department of Urbanism, the Netherlands

E-mail: yan.song@tudelft.nl

Arjan van Timmeren

Delft University of Technology

Department of Urbanism, the Netherlands

E-mail: A.vanTimmeren@tudelft.nl

Alexander Wandl

Delft University of Technology

Department of Urbanism,

the Netherlands

E-mail: A.Wandl@tudelft.nl

Keywords:

urban metabolism, urban metabolism indicator,

sustainability,

CIMO approach approach to quantifying energy and resource use and supply in the modern urban system. It is a multidisciplinary approach focused on providing insight into the behaviour of cities for drafting effective proposals for a more humane and ecologically responsible future. Urban metabolism indicators could play an important role in promoting the science and practice of urban metabolism for sustainability. This paper presents a systematic review of literature centred on defining sustainabilityaimed urban metabolism indicators to improve the integration of urban metabolism and urban sustainability. Furthermore, this paper concentrates on two indicator sets (emergy synthesis and material flow analysis [MFA]), examining the relationship between these indicators and the three dimensions of sustainability (environment, economy, and society) in the literature. The paper thus builds a bridge between urban metabolism and urban sustainability in the hope that urban metabolism indicators can be used to measure and assess urban sustainability.

\section{Introduction}

With the onset of the Industrial Revolution and the rise of capitalism, the modern world has moved into an era of resource exploitation and intensity never seen before. To bring modern society's demands for energy, water, air, and other resources in line with the finite reserves of the earth, more needs to be done to quantify resource usage and to understand its political, economic, and ecological context.

One promising framework that has been advanced as an approach to quantifying energy and resource use and supply in modern society is "urban metabolism" (Ferrao-Fernandez 2013, Acebillo 2012). Wolman (1965) was the first to claim that the "metabolism" of a city comprises all the resources required by an urban system for economic production processes and the sum of waste streams emitted as a con-

Regional Statistics, Vol. 9. No. 1. 2019: 54-71; DOI: 10.15196/RS090103 
sequence of consumption. Urban metabolism can be defined as "the sum total of the technical and socio-economic processes that occur in cities, resulting in economic growth, production of energy, and elimination of waste" (Kennedy et al. 2007). In modern reference, urban metabolism has been distinguished as an analytical tool used to understand the essential energy, material, and waste streams between cities, their surrounding regions, and the planet. It is tangential to concepts of regenerative design, cradle-to-cradle design, and the emerging academic fields of industrial ecology and biomimicry (Richards et al. 1994, Benyus 2009, McDonoughBraungart 2002, van Timmeren 2013, Decker et al. 2000). Urban metabolism is an approach to modelling complex urban systems' material and energy streams as if the cities were organisms in the ecosystem (Fischer-Kowalski 2002, van Timmeren 2013). Urban metabolism thus forms a multi-disciplinary research domain that focuses on providing insights into the behaviour of cities for the purpose of advancing effective proposals for a more humane and ecologically responsible future.

\section{Methodology and review of urban metabolism indicators for improving knowledge integration}

The main objective of this paper is to present a systematic review of literature centred on categorising sustainability-aimed urban metabolism indicators to improve the integration of urban metabolism and urban sustainability. To achieve this, relevant research articles on urban metabolism were reviewed after searching through the Scopus database twice in October 2018. The literature was selected using three filters. First, 144 articles focusing on urban metabolism indicators and the concepts of sustainability were selected based on the content of their abstracts, titles, and keywords. Subsequently, these articles were filtered by subject area (environmental science and social science), source type (journals), document type (article), and language (due to language competence, two Spanish articles were excluded), resulting in 84 articles. Finally, these articles were read in depth and only those that provided specific indicator sets and mechanisms with sustainability concepts were selected, using qualitative content analysis. The articles that were excluded fell into the following categories: 1 . no specific indicator set proposed; 2 . sole focus on indicators in a limited research area; 3. indicator set only suitable in a specific site; and 4. an urban sustainability indicator set proposed rather than an urban metabolism indicator set. This filter process resulted in a total of 23 articles. Next, the adapted context, indicator, mechanism, outcome (CIMO) approach was applied to systematically capture the article information related to the main objective of the research. In our case, context (C) includes the research background and objective; indicator (I) is the quantifying item of each aspect, which is the intervention part of the original CIMO approach; mechanism $(\mathrm{M})$ refers to the method of measuring or evaluating the indicator; and outcome $(\mathrm{O})$ comprises the expected effects, which can be implemented

Regional Statistics, Vol. 9. No. 1. 2019: 54-71; DOI: 10.15196/RS090103 
in the general cases. Based on the results of the CIMO analysis, this paper concentrates on two indicator sets (emergy synthesis and MFA), analysing the relationship between these indicators and the three dimensions of sustainability (environment, economy, and society) in the literature. This could be the selection basis of sustainability-aimed urban metabolism indicators in future research.

The CIMO approach was used to process systematically the information in the 23 articles according to the objective of each paper. This approach originated from the domain of planning research (Soria-Lara et al. 2016, Straatemeier et al. 2010). The CIMO approach states that in a problematic context (C), the mechanism (M) can be used to explore generative intervention (I) to deliver some outcome (O) (Denyer et al. 2008). It offers a useful framework to identify and assess the mechanism and indicator sets in the selected literature. In this paper, we adopt the CIMO approach by using urban metabolism and sustainability indicators to represent I as shown in Table 1.

Table 1

Summary of mechanisms and indicators of urban metabolism and sustainability in the selected articles

\begin{tabular}{|c|c|c|c|c|}
\hline & Context & Indicators & Mechanism & Outcomes \\
\hline $\begin{array}{l}\text { Barles } \\
(2009)\end{array}$ & $\begin{array}{l}\text { Presents the results } \\
\text { of a research project } \\
\text { aimed at } \\
\text { a. examining the } \\
\text { feasibility of MFA on } \\
\text { a regional and urban } \\
\text { scale in France; } \\
\text { b. selecting the most } \\
\text { appropriate method; } \\
\text { c. identifying the } \\
\text { available data; and } \\
\text { d. calculating the } \\
\text { material balance for a } \\
\text { specific case }\end{array}$ & $\begin{array}{l}\text { Balancing inputs and } \\
\text { outputs, domestic mate- } \\
\text { rial consumption, direct } \\
\text { material input and out- } \\
\text { put, local and exported } \\
\text { processed output, the } \\
\text { net addition to stock, } \\
\text { total domestic output, } \\
\text { total material input, total } \\
\text { material output, and } \\
\text { requirement }\end{array}$ & MFA & $\begin{array}{l}\text { It reveals the need } \\
\text { for new public poli- } \\
\text { cies, especially con- } \\
\text { cerning waste man- } \\
\text { agement - to reduce } \\
\text { construction material } \\
\text { imports - and urban } \\
\text { planning - to reduce } \\
\text { their consumption. In } \\
\text { addition, it states the } \\
\text { need for more re- } \\
\text { search and the devel- } \\
\text { opment of action } \\
\text { plans to link urban } \\
\text { and agricultural poli- } \\
\text { cies to improve the } \\
\text { use of urban fertiliz- } \\
\text { ers to favour local } \\
\text { food supply. }\end{array}$ \\
\hline
\end{tabular}

Regional Statistics, Vol. 9. No. 1. 2019: 54-71; DOI: 10.15196/RS090103 
A literature review and categorisation of sustainability-aimed urban metabolism indicators: a context, indicator, mechanism, outcome analysis

\begin{tabular}{|c|c|c|c|c|}
\hline & Context & Indicators & Mechanism & Outcomes \\
\hline $\begin{array}{l}\text { Browne et } \\
\text { al. (2012) }\end{array}$ & $\begin{array}{l}\text { Seeks to apply a } \\
\text { number of biophysical } \\
\text { sustainability metrics } \\
\text { to an Irish city-region } \\
\text { to evaluate the effect } \\
\text { of methodological } \\
\text { pluralism when meas- } \\
\text { uring urban sustaina- } \\
\text { bility and to deter- } \\
\text { mine the outcome of } \\
\text { using more than one } \\
\text { method when measur- } \\
\text { ing the sustainability } \\
\text { of the same system } \\
\text { boundary at a city- } \\
\text { region level }\end{array}$ & $\begin{array}{l}\text { 1. Measuring energy flows } \\
\text { for } \\
\text { a. solid fuels, including } \\
\text { coking coal, steam coal, } \\
\text { sub-bituminous coal, } \\
\text { lignite/ brown coal, peat, } \\
\text { oven and gas coke, patent } \\
\text { fuel, and brown coal peat } \\
\text { briquettes, } \\
\text { b. oil, including crude oil, } \\
\text { refinery feedstocks, and } \\
\text { petroleum products, } \\
\text { c. liquid natural gas; } \\
\text { 2. Measuring energy and } \\
\text { emissions metabolism } \\
\text { estimates: } \\
\text { a. TFC of energy in a } \\
\text { particular sector, dis- } \\
\text { aggregated by fuel type, } \\
\text { b. total emissions from } \\
\text { that sector, including } \\
\text { greenhouse gas emissions } \\
\text { and air pollution, } \\
\text { c. the ratio of total emis- } \\
\text { sions to TFC in a particu- } \\
\text { lar year }\end{array}$ & $\begin{array}{l}\text { 1. Energy } \\
\text { flow } \\
\text { accounting } \\
\text { 2. Energy } \\
\text { flow- } \\
\text { metabolism } \\
\text { ratio analysis }\end{array}$ & $\begin{array}{l}\text { It develops an ap- } \\
\text { proach to measuring } \\
\text { energy metabolism by } \\
\text { outlining and applying } \\
\text { the 'energy flow- } \\
\text { metabolism ratio } \\
\text { analysis' methodology, } \\
\text { which is used to } \\
\text { measure the ratio of } \\
\text { greenhouse gas emis- } \\
\text { sions as a function of } \\
\text { energy material inputs. }\end{array}$ \\
\hline $\begin{array}{l}\text { Chen-Chen } \\
\text { (2014) }\end{array}$ & $\begin{array}{l}\text { Investigates a way to } \\
\text { balance economic } \\
\text { development and } \\
\text { ecosystem health } \\
\text { within a workable } \\
\text { framework }\end{array}$ & $\begin{array}{l}\text { 1. Sets of MFA, life cycle } \\
\text { analysis, exergy-based } \\
\text { analysis, and emergy } \\
\text { analysis; } \\
\text { 2. Ecological network } \\
\text { analysis sets }\end{array}$ & $\begin{array}{l}\text { 1. Element- } \\
\text { based method } \\
2 . \text { Structure- } \\
\text { based method }\end{array}$ & $\begin{array}{l}\text { It is an up-to-date } \\
\text { inspection of integrat- } \\
\text { ing eco-indicators, } \\
\text { which has both wide } \\
\text { academic interest } \\
\text { among interdisciplinary } \\
\text { scientific boards and } \\
\text { realistic application } \\
\text { meaning for better } \\
\text { urban management. }\end{array}$ \\
\hline $\begin{array}{l}\text { Chen-Wang } \\
\text { (2014) }\end{array}$ & $\begin{array}{l}\text { Gathers insights from } \\
\text { global cities, identifies } \\
\text { best practices interna- } \\
\text { tionally, and discusses } \\
\text { how cities and regions } \\
\text { can play a leading role } \\
\text { in creating a sustaina- } \\
\text { ble society }\end{array}$ & $\begin{array}{l}\text { 1. A new multi-layered } \\
\text { indicator set for urban } \\
\text { metabolism studies: defi- } \\
\text { nition information (spatial } \\
\text { boundaries, constitu-ent } \\
\text { cities, population, econ- } \\
\text { omy), biophysical charac- } \\
\text { teristics (climate, popula- } \\
\text { tion density, building } \\
\text { floor area), and metabolic } \\
\text { flows (water, waste, mate- } \\
\text { rials, and all types of } \\
\text { energy) of megacities; } \\
\text { 2. Accounting scheme } \\
\text { and its indicators from } 13 \\
\text { flow elements and } 9 \text { fund } \\
\text { elements }\end{array}$ & $\begin{array}{l}\text { 1. Multi- } \\
\text { layered urban } \\
\text { metabolism } \\
\text { 2. MuSIASEM }\end{array}$ & $\begin{array}{l}\text { It probes into the } \\
\text { regulatory measures to } \\
\text { optimise the configu- } \\
\text { ration of water re- } \\
\text { sources and to realize } \\
\text { the integration of } \\
\text { fundamental research } \\
\text { innovation and man- } \\
\text { agement practice, } \\
\text { thus, providing rea- } \\
\text { sonable decision sup- } \\
\text { port for the nexus of } \\
\text { water security, ecolog- } \\
\text { ical security, and sus- } \\
\text { tainable socio- } \\
\text { economic develop- } \\
\text { ment of cities and } \\
\text { regions. }\end{array}$ \\
\hline
\end{tabular}

Regional Statistics, Vol. 9. No. 1. 2019: 54-71; DOI: 10.15196/RS090103 


\begin{tabular}{|c|c|c|c|c|}
\hline & Context & Indicators & Mechanism & Outcomes \\
\hline $\begin{array}{l}\text { Chifari et al. } \\
\text { (2017) }\end{array}$ & $\begin{array}{l}\text { Presents a useful } \\
\text { method for organiz- } \\
\text { ing a process of pro- } \\
\text { duction and the use } \\
\text { of scientific infor- } \\
\text { mation in which both } \\
\text { scientists and other } \\
\text { social actors can have } \\
\text { a bidirectional and } \\
\text { constructive exchange } \\
\text { of information }\end{array}$ & $\begin{array}{l}\text { Occupied land, power } \\
\text { capacity electrical ma- } \\
\text { chinery, power capacity } \\
\text { thermal machinery, } \\
\text { process heat consump- } \\
\text { tion, electricity con- } \\
\text { sumption, fuel consump- } \\
\text { tion, water consumption, } \\
\text { fixed investments, run- } \\
\text { ning costs, cost of ex- } \\
\text { ports, electricity revenue, } \\
\text { recyclables revenue, } \\
\text { subsidies for electricity } \\
\text { production }\end{array}$ & MuSIASEM & $\begin{array}{l}\text { Its approach provides } \\
\text { a detailed characteri- } \\
\text { zation of the material } \\
\text { balance of waste flows } \\
\text { through the Municipal } \\
\text { Solid Waste Manage- } \\
\text { ment System. }\end{array}$ \\
\hline $\begin{array}{l}\text { Chrysoulakis } \\
\text { et al. (2013) }\end{array}$ & $\begin{array}{l}\text { Improves the com- } \\
\text { munication of new } \\
\text { biophysical } \\
\text { knowledge to end- } \\
\text { users (such as urban } \\
\text { planners, architects, } \\
\text { and engineers) with a } \\
\text { focus on sustainable } \\
\text { urban metabolism }\end{array}$ & $\begin{array}{l}\text { The indicators set used } \\
\text { in BRIDGE evaluations: } \\
\text { a. energy, } \\
\text { b. thermal comfort, } \\
\text { c. water, } \\
\text { d. greenhouse gases, } \\
\text { e. land use, } \\
\text { f. mobility/accessibility, } \\
\text { g. social inclusion, } \\
\text { h. human well-being, } \\
\text { j. cost of proposed de- } \\
\text { velopment, and k. effects } \\
\text { on the local economy } \\
\text { (employment and reve- } \\
\text { nue) }\end{array}$ & $\begin{array}{l}\text { Based on } \\
\text { sustainability } \\
\text { objectives and } \\
\text { associated } \\
\text { indicators } \\
\text { addressing } \\
\text { specific as- } \\
\text { pects of ur- } \\
\text { ban metabo- } \\
\text { lism }\end{array}$ & $\begin{array}{l}\text { It shows how a tool } \\
\text { like the BRIDGE DSS } \\
\text { may not simplify the } \\
\text { urban planning pro- } \\
\text { cess, but can help } \\
\text { urban planners deal } \\
\text { more adequately with } \\
\text { its complexity. Alt- } \\
\text { hough implementa- } \\
\text { tion of the DSS dur- } \\
\text { ing planning processes } \\
\text { may be constrained by } \\
\text { lack of resources and } \\
\text { skills at municipalities, } \\
\text { practitioners can gain } \\
\text { significant insight for } \\
\text { more informed deci- } \\
\text { sion-making. }\end{array}$ \\
\hline $\begin{array}{l}\text { Geng et al. } \\
\text { (2011) }\end{array}$ & $\begin{array}{l}\text { Employs the MSI- } \\
\text { ASM approach to } \\
\text { evaluate regional } \\
\text { societal and ecosys- } \\
\text { tem metabolism in } \\
\text { China }\end{array}$ & $\begin{array}{l}\text { Hour-based human time, } \\
\text { Joule-based exosomatic } \\
\text { energy throughput, } \\
\text { exosomatic metabolism } \\
\text { rate, and bio-economic } \\
\text { pressure }\end{array}$ & MSIASM & $\begin{array}{l}\text { It indicates that the } \\
\text { MSIASM method } \\
\text { provides a feasible } \\
\text { way for different } \\
\text { levels of government } \\
\text { to recognize the main } \\
\text { barriers and challeng- } \\
\text { es to development. } \\
\end{array}$ \\
\hline $\begin{array}{l}\text { Goldstein et } \\
\text { al. (2013) }\end{array}$ & $\begin{array}{l}\text { Advances the ability } \\
\text { to quantify environ- } \\
\text { mental impacts of } \\
\text { cities by modelling } \\
\text { pressures embedded } \\
\text { in the flows upstream } \\
\text { (entering) and down- } \\
\text { stream (leaving) of } \\
\text { the actual urban } \\
\text { systems studied, and } \\
\text { by introducing an } \\
\text { advanced suite of } \\
\text { indicators }\end{array}$ & $\begin{array}{l}\text { Indicators of environ- } \\
\text { mental exchanges (mate- } \\
\text { rial and energy inputs, } \\
\text { air, soil, water emissions, } \\
\text { etc.) for the modelled } \\
\text { processes }\end{array}$ & UM-LCA & $\begin{array}{l}\text { It shows that the } \\
\text { urban metabolism } \\
\text { approach can be } \\
\text { embedded within the } \\
\text { process-based LCA } \\
\text { framework, yielding } \\
\text { a hybrid UM-LCA } \\
\text { model that can pro- } \\
\text { vide a complete } \\
\text { measurement of the } \\
\text { environmental pres- } \\
\text { sures exerted by } \\
\text { a city. }\end{array}$ \\
\hline
\end{tabular}


A literature review and categorisation of sustainability-aimed urban metabolism indicators: a context, indicator, mechanism, outcome analysis

\begin{tabular}{|c|c|c|c|c|}
\hline & Context & Indicators & Mechanism & Outcomes \\
\hline $\begin{array}{l}\text { González et } \\
\text { al. (2013) }\end{array}$ & $\begin{array}{l}\text { Enables the formula- } \\
\text { tion of planning and } \\
\text { policy recommenda- } \\
\text { tions to promote the } \\
\text { efficient use of re- } \\
\text { sources and enhance } \\
\text { environmental quality } \\
\text { in urban areas }\end{array}$ & $\begin{array}{l}\text { Water (i.e. water balance, } \\
\text { including evapotranspira- } \\
\text { tion and run-off, and risk } \\
\text { of flooding); air and } \\
\text { climate (i.e. air quality in } \\
\text { terms of pollutant con- } \\
\text { centration and disper- } \\
\text { sion; as well as } \mathrm{CO}_{2} \\
\text { emissions, carbon sinks, } \\
\text { and energy balance); and } \\
\text { material assets (i.e. ener- } \\
\text { gy/ fuel consumption } \\
\text { and associated heat } \\
\text { fluxes, including heat } \\
\text { island effects) }\end{array}$ & $\begin{array}{l}\text { Analytical } \\
\text { hierarchical } \\
\text { process } \\
\text { multi-criteria } \\
\text { assessment } \\
\text { technique }\end{array}$ & $\begin{array}{l}\text { It shows how the } \\
\text { DSS can support } \\
\text { impact assessment } \\
\text { processes associated } \\
\text { with the development } \\
\text { and implementation } \\
\text { of plans and projects, } \\
\text { as well as contribute } \\
\text { to monitoring and } \\
\text { forecasting indicator } \\
\text { performance in a } \\
\text { planning context. }\end{array}$ \\
\hline $\begin{array}{l}\text { Hoekman- } \\
\text { von Blottnitz } \\
\text { (2017) }\end{array}$ & $\begin{array}{l}\text { Contributes to the } \\
\text { number of urban } \\
\text { metabolism case } \\
\text { studies using } \\
\text { a standardized meth- } \\
\text { odology }\end{array}$ & $\begin{array}{l}\text { Domestic extraction } \\
\text { used, imports, exports, } \\
\text { domestic processed } \\
\text { output, direct material } \\
\text { input, domestic material } \\
\text { consumption, physical } \\
\text { trade balance, and direct } \\
\text { material output }\end{array}$ & $\begin{array}{l}\text { Economy- } \\
\text { wide MFA }\end{array}$ & $\begin{array}{l}\text { The study provides } \\
\text { insights into the city's } \\
\text { metabolism through } \\
\text { various indicators } \\
\text { including direct mate- } \\
\text { rial input, domestic } \\
\text { material consump- } \\
\text { tion, and direct mate- } \\
\text { rial output, among } \\
\text { others. }\end{array}$ \\
\hline $\begin{array}{l}\text { Hoornweg et } \\
\text { al. (2012) }\end{array}$ & $\begin{array}{l}\text { Presents urban me- } \\
\text { tabolism case studies, } \\
\text { the data gathering } \\
\text { challenges outlined, } \\
\text { and the recommenda- } \\
\text { tions made as to how } \\
\text { local governments } \\
\text { can institutionalize } \\
\text { the collection of } \\
\text { metabolism infor- } \\
\text { mation and use it to } \\
\text { inform local sustaina- } \\
\text { bility programs and } \\
\text { projects }\end{array}$ & $\begin{array}{l}\text { Inflows, outflows, inter- } \\
\text { nal flows, storage and } \\
\text { production of biomass, } \\
\text { minerals, water, and } \\
\text { energy }\end{array}$ & $\begin{array}{l}\text { Abbreviated } \\
\text { urban metab- } \\
\text { olism } \\
\text { (a standard- } \\
\text { ized listing of } \\
\text { urban metab- } \\
\text { olism } \\
\text { measures that } \\
\text { ideally should } \\
\text { be included in } \\
\text { basic level } \\
\text { reporting) }\end{array}$ & $\begin{array}{l}\text { It states that by mak- } \\
\text { ing citizens and com- } \\
\text { panies more aware of } \\
\text { their own impact on } \\
\text { their city's metabo- } \\
\text { lism, advances in } \\
\text { information and } \\
\text { communications } \\
\text { technology and open } \\
\text { data can help promote } \\
\text { society-wide collabo- } \\
\text { ration, smarter public } \\
\text { decision-making, and } \\
\text { a 'race to the top' to } \\
\text { improve a city's re- } \\
\text { source efficiency and } \\
\text { sustainability. }\end{array}$ \\
\hline $\begin{array}{l}\text { Huang-Hsu } \\
\text { (2003) }\end{array}$ & $\begin{array}{l}\text { Incorporates resource } \\
\text { and MFA to investi- } \\
\text { gate the Taipei area's } \\
\text { urban sustainability } \\
\text { due to urban con- } \\
\text { struction }\end{array}$ & $\begin{array}{l}\text { Indicators include the } \\
\text { categories of } \\
\text { a. intensity of resource } \\
\text { consumption; } \\
\text { b. inflow/outflow ratio; } \\
\text { c. urban liveability; } \\
\text { d. efficiency of urban } \\
\text { metabolism; and } \\
\text { e. emergy evaluation of } \\
\text { urban metabolism }\end{array}$ & $\begin{array}{l}\text { MFA and } \\
\text { emergy syn- } \\
\text { thesis analysis }\end{array}$ & $\begin{array}{l}\text { It shows that the } \\
\text { material flow account- } \\
\text { ing approach and the } \\
\text { emergy evaluation of } \\
\text { urban construction } \\
\text { have important impli- } \\
\text { cations for evaluating } \\
\text { the sustainability of } \\
\text { urban development. }\end{array}$ \\
\hline
\end{tabular}

Regional Statistics, Vol. 9. No. 1. 2019: 54-71; DOI: 10.15196/RS090103 


\begin{tabular}{|c|c|c|c|c|}
\hline & Context & Indicators & & Outcomes \\
\hline $\begin{array}{l}\text { Inostroza } \\
(2014)\end{array}$ & $\begin{array}{l}\text { Proposes a new indi- } \\
\text { cator to measure this } \\
\text { process of material } \\
\text { accumulation, namely, } \\
\text { technomass }\end{array}$ & $\begin{array}{l}\text { Technomass aspects } \\
\text { (e.g. buildings, roads, } \\
\text { cars, furniture, clothes, } \\
\text { machines, and techno- } \\
\text { logical assets) and flows } \\
\text { (e.g. water, food, energy, } \\
\text { and supporting flows) }\end{array}$ & MFA & $\begin{array}{l}\text { The study shows, in } \\
\text { metabolic terms, how } \\
\text { the indicator looks } \\
\text { into the black box, } \\
\text { providing the possibil- } \\
\text { ity of linking metabol- } \\
\text { ic behaviours with } \\
\text { urban forms and } \\
\text { attempting to fill the } \\
\text { gap between urban } \\
\text { planning, urban me- } \\
\text { tabolism, and MFA. } \\
\text { This new indicator } \\
\text { offers a broad scope } \\
\text { of applications. Fur- } \\
\text { ther possibilities and } \\
\text { links to urban re- } \\
\text { search and policy- } \\
\text { making are explored } \\
\text { in the discussion } \\
\text { section. }\end{array}$ \\
\hline $\begin{array}{l}\text { Kennedy- } \\
\text { Hoornweg } \\
(2012)\end{array}$ & $\begin{array}{l}\text { Presents a standard- } \\
\text { ized, comprehensive } \\
\text { urban metabolism } \\
\text { framework and some } \\
\text { degree of agreement } \\
\text { on which parameters, } \\
\text { out of the many pos- } \\
\text { sible, should ideally be } \\
\text { included in basic level } \\
\text { reporting }\end{array}$ & $\begin{array}{l}\text { Inflows, outflows, inter- } \\
\text { nal flows, storage, and } \\
\text { production of biomass, } \\
\text { minerals, water, and } \\
\text { energy }\end{array}$ & $\begin{array}{l}\text { Urban me- } \\
\text { tabolism } \\
\text { framework }\end{array}$ & $\begin{array}{l}\text { The study results } \\
\text { indicate that the urban } \\
\text { metabolism method- } \\
\text { ology is sufficiently } \\
\text { robust, standardized, } \\
\text { and practical to allow } \\
\text { quick uptake by cities } \\
\text { and ease of continued } \\
\text { monitoring. }\end{array}$ \\
\hline $\begin{array}{l}\text { Kennedy et } \\
\text { al. (2014) }\end{array}$ & $\begin{array}{l}\text { Proposes a new 'mul- } \\
\text { ti-layered' indicator } \\
\text { set for urban metabo- } \\
\text { lism studies in meg- } \\
\text { acities }\end{array}$ & $\begin{array}{l}\text { Information on the defini- } \\
\text { tion (spatial boundaries, } \\
\text { constituent cities, popula- } \\
\text { tion, economy), biophysi- } \\
\text { cal characteristics (climate, } \\
\text { population density, build- } \\
\text { ing floor area), and meta- } \\
\text { bolic flows (water, waste, } \\
\text { materials, and all types of } \\
\text { energy) of megacities }\end{array}$ & $\begin{array}{l}\text { Multi-layered } \\
\text { urban metab- } \\
\text { olism indica- } \\
\text { tor set }\end{array}$ & $\begin{array}{l}\text { It shows that use of } \\
\text { the standardized } \\
\text { indicator set will ease } \\
\text { inter-city comparisons } \\
\text { of urban metabolism, } \\
\text { while enhancing } \\
\text { knowledge of megaci- } \\
\text { ties and their trans- } \\
\text { formation into sus- } \\
\text { tainable systems. } \\
\end{array}$ \\
\hline $\begin{array}{l}\text { Kennedy et } \\
\text { al. (2015) }\end{array}$ & $\begin{array}{l}\text { Quantifies the energy } \\
\text { and material flows of } \\
\text { the world's } 27 \text { meg- } \\
\text { acities, based on } 2010 \\
\text { population, and iden- } \\
\text { tifies physical and } \\
\text { economic characteris- } \\
\text { tics that underlie the } \\
\text { resource flows at } \\
\text { multiple scales }\end{array}$ & $\begin{array}{l}\text { Resource flows of electric- } \\
\text { ity consumption, heating } \\
\text { and industrial fuel use, } \\
\text { ground transportation } \\
\text { energy use, water con- } \\
\text { sumption, waste genera- } \\
\text { tion, and steel production } \\
\text { in terms of heating- } \\
\text { degree-days, urban forms, } \\
\text { economic activity, and } \\
\text { population growth }\end{array}$ & MFA & $\begin{array}{l}\text { It shows that overall } \\
\text { energy and material } \\
\text { flows vary considera- } \\
\text { bly among megacities. } \\
\text { It provides previously } \\
\text { unidentified insights } \\
\text { into the relationship } \\
\text { between electricity } \\
\text { consumption and } \\
\text { urban forms. }\end{array}$ \\
\hline
\end{tabular}


A literature review and categorisation of sustainability-aimed urban metabolism indicators: a context, indicator, mechanism, outcome analysis

\begin{tabular}{|c|c|c|c|c|}
\hline & Context & Indicators & Mechanism & Outcomes \\
\hline $\begin{array}{l}\text { Li et al. } \\
(2016)\end{array}$ & $\begin{array}{l}\text { Applies MFA in } \\
\text { conjunction with } \\
\text { specific socio- } \\
\text { economic indicators } \\
\text { to model urban me- } \\
\text { tabolism and evaluate } \\
\text { appropriate urban } \\
\text { metabolism changes } \\
\text { for the study case }\end{array}$ & $\begin{array}{l}\text { Four major component } \\
\text { inputs and outputs of the } \\
\text { city: metals and industrial } \\
\text { minerals, energy con- } \\
\text { sumption, construction } \\
\text { materials and biomass } \\
\text { (predominantly from the } \\
\text { surrounding farming } \\
\text { areas) }\end{array}$ & MFA & $\begin{array}{l}\text { The study shows that } \\
\text { MFA techniques can } \\
\text { be used as valuable } \\
\text { tools for understand- } \\
\text { ing urban metabolism, } \\
\text { evaluating urban } \\
\text { sustainability, and } \\
\text { suggesting strategies } \\
\text { for timely addressing } \\
\text { urban sustainability } \\
\text { issues. }\end{array}$ \\
\hline $\begin{array}{l}\text { Rosado et al. } \\
(2016)\end{array}$ & $\begin{array}{l}\text { Contributes to the } \\
\text { discourse on urban } \\
\text { area typology as well } \\
\text { as to identifying ur- } \\
\text { ban metabolism char- } \\
\text { acteristics }\end{array}$ & $\begin{array}{l}\text { Eight urban metabolism } \\
\text { characteristics: needs, } \\
\text { accumulation, depend- } \\
\text { ency, support, efficiency, } \\
\text { diversity of processes, } \\
\text { self-sufficiency, and } \\
\text { pressure on the envi- } \\
\text { ronment }\end{array}$ & MFA & $\begin{array}{l}\text { It presents the extent } \\
\text { of the imbalance } \\
\text { between the types of } \\
\text { materials extracted, } \\
\text { consumed, and } \\
\text { stocked, which makes } \\
\text { urban areas vulnerable } \\
\text { to external changes in } \\
\text { resource supplies. }\end{array}$ \\
\hline $\begin{array}{l}\text { Sun et al. } \\
(2017)\end{array}$ & $\begin{array}{l}\text { Develops an integrat- } \\
\text { ed MFA and emergy } \\
\text { evaluation model to } \\
\text { investigate the envi- } \\
\text { ronmental and eco- } \\
\text { logical benefits of } \\
\text { urban industrial sym- } \\
\text { biosis implementation }\end{array}$ & $\begin{array}{l}\text { Urban statistics (urban } \\
\text { level input and output } \\
\text { flows), and micro level } \\
\text { material and energy flow } \\
\text { analysis (input and out- } \\
\text { put flow within the } \\
\text { symbiotic network) }\end{array}$ & $\begin{array}{l}\text { Integrated } \\
\text { MFA }\end{array}$ & $\begin{array}{l}\text { This paper provides } \\
\text { a useful modelling } \\
\text { app-roach to under- } \\
\text { stand the ecological } \\
\text { benefits and trade-offs } \\
\text { of local circular econ- } \\
\text { omy prac-tices and } \\
\text { fundamental insights } \\
\text { on natural capital } \\
\text { accounting. }\end{array}$ \\
\hline $\begin{array}{l}\text { Yang et al. } \\
(2012)\end{array}$ & $\begin{array}{l}\text { Assesses resource } \\
\text { exchanges and envi- } \\
\text { ronmental emissions, } \\
\text { urban household } \\
\text { metabolism is investi- } \\
\text { gated using an emergy } \\
\text { synthesis framework }\end{array}$ & $\begin{array}{l}\text { The emergy self- } \\
\text { sufficiency ratio and the } \\
\text { emergy } \\
\text { investment ratio }\end{array}$ & $\begin{array}{l}\text { Emergy syn- } \\
\text { thesis analysis }\end{array}$ & $\begin{array}{l}\text { It helps foster alterna- } \\
\text { tive household con- } \\
\text { sumption strategies } \\
\text { that could result in } \\
\text { more equitable re- } \\
\text { source allocation and } \\
\text { effective mitigation of } \\
\text { cross-boundary envi- } \\
\text { ronmental influences. }\end{array}$ \\
\hline $\begin{array}{l}\text { Yang et al. } \\
(2014)\end{array}$ & $\begin{array}{l}\text { Presents how creating } \\
\text { sustainable cities has } \\
\text { led to increasing } \\
\text { concern over achiev- } \\
\text { ing healthy spatial } \\
\text { metabolic interactions } \\
\text { and system sustaina- } \\
\text { bility }\end{array}$ & $\begin{array}{l}\text { Emergy-based indicators: } \\
\text { renewable resources, } \\
\text { non-renewable re- } \\
\text { sources, local agriculture } \\
\text { products, agricultural } \\
\text { consumption, agricultur- } \\
\text { al pollutants, residents' } \\
\text { consumption, imports, } \\
\text { exports }\end{array}$ & $\begin{array}{l}\text { Emergy syn- } \\
\text { thesis analysis }\end{array}$ & $\begin{array}{l}\text { It shows how emergy } \\
\text { synthesis can effec- } \\
\text { tively integrate eco- } \\
\text { nomic, social, and } \\
\text { ecological dimensions } \\
\text { and provide insights } \\
\text { into cross-boundary } \\
\text { metabolic interactions } \\
\text { and system metabolic } \\
\text { sustainability. }\end{array}$ \\
\hline
\end{tabular}




\begin{tabular}{|c|c|c|c|c|}
\hline & Context & Indicators & Mechanism & Outcomes \\
\hline $\begin{array}{l}\text { Zhai et al. } \\
\text { (2018) }\end{array}$ & $\begin{array}{l}\text { Combs through in- } \\
\text { put-output analyses } \\
\text { with ecological net- } \\
\text { work analysis to help } \\
\text { academics shed light } \\
\text { on complicated sys- } \\
\text { tem interactions and } \\
\text { interior energy flows }\end{array}$ & $\begin{array}{l}\text { Embodied ecological } \\
\text { energy element intensity, } \\
\text { direct integral flow con- } \\
\text { trol intensity, average } \\
\text { mutual information, } \\
\text { residual uncertainty }\end{array}$ & $\begin{array}{l}\text { Energy eco- } \\
\text { logical net- } \\
\text { work model } \\
\text { and Input- } \\
\text { output analy- } \\
\text { sis }\end{array}$ & $\begin{array}{l}\text { This is a detailed study } \\
\text { on the direction of } \\
\text { energy; the flows } \\
\text { uncover the relation- } \\
\text { ship between social } \\
\text { production activities } \\
\text { and energy circulation. } \\
\text { A thorough insight } \\
\text { into robustness crea- } \\
\text { tively provides a refer- } \\
\text { ence for improving the } \\
\text { system efficiency. }\end{array}$ \\
\hline $\begin{array}{l}\text { Zhang et al. } \\
\text { (2013) }\end{array}$ & $\begin{array}{l}\text { Identifies the main } \\
\text { metabolic actors } \\
\text { responsible for these } \\
\text { problems and anal- } \\
\text { yses the characteris- } \\
\text { tics of their metabolic } \\
\text { structure. }\end{array}$ & $\begin{array}{l}\text { Metabolic evaluation } \\
\text { indicators: metabolic } \\
\text { scale; metabolic intensity; } \\
\text { metabolic efficiency } \\
\text { (resources); metabolic } \\
\text { impact (wastes). }\end{array}$ & $\begin{array}{l}\text { The urban } \\
\text { metabolic } \\
\text { network } \\
\text { model }\end{array}$ & $\begin{array}{l}\text { It states that this } \\
\text { improved resolution } \\
\text { would provide a } \\
\text { clearer picture of the } \\
\text { network's characteris- } \\
\text { tics, which cannot be } \\
\text { represented accurately } \\
\text { by small networks, } \\
\text { such as the one ex- } \\
\text { ample in the study, } \\
\text { and would provide a } \\
\text { more realistic simula- } \\
\text { tion of an urban } \\
\text { metabolic system. }\end{array}$ \\
\hline
\end{tabular}

Note: Results are listed alphabetically. MFA - material flow analysis; TFC - total final consumption; MuSIASEM - multi-scale integrated analysis of societal and ecosystem metabolism; MSIASM - multi-scale integrated analysis of societal metabolism; DSS - decision support system; UM-LCA - urban metabolism-life cycle assessment

From the CIMO literature review, there are two basic accounting and assessment mechanisms for urban metabolism indicators based on MFA and energy (emergy synthesis) analysis. Most recent urban metabolism mechanisms expand on or supplement these two mechanisms, such as the integrated MFA, the multi-layered urban metabolism indicator framework, the abbreviated urban metabolism, and the energy flow-metabolism ratio analysis (Sun et al. 2017, Kennedy et al. 2014, Kennedy-Hoornweg 2012, Hoornweg et al. 2012, Chen-Wang 2014, Browne et al. 2012). The MFA begins with material classification and concludes with a balance sheet that accounts for the categorised materials (Zhang et al. 2015). Similarly, emergy synthesis analysis starts with multiplying each flow of energy by its solar transformity and results in the assessment of emergy flow analysis (Zhang et al. 2009). Recently, researchers have begun to explore the possibilities of using life cycle assessment to account for and assess urban metabolism, which will be a further development of the model using consequential life cycle inventories (Zhang et al. 2013, Goldstein et al. 2013).

Regional Statistics, Vol. 9. No. 1. 2019: 54-71; DOI: 10.15196/RS090103 
A literature review and categorisation of sustainability-aimed urban metabolism indicators: a context, indicator, mechanism, outcome analysis

\section{An approach for integrating urban metabolism indicators and sustainability}

As urbanisation develops, so do environmental problems associated with it (Yang et al. 2017). Therefore, cities are seeking transformative methods to support sustainability in the future. To date, there are several urban-centric approaches that attempt to initiate radical innovations in this area such as the compact city (Dempsey 2010), smart growth (Kolbadi et al. 2015), the eco-city (Caprotti 2014), the zero-carbon city (Abbasi et al. 2012), the smart city (Townsend 2013), and the just city (Fainstein 2010). All of these schemes contain urban sustainability characteristics (Wei 2011, van Timmeren et al. 2015). The term 'sustainability' refers to a particular relationship between the human and environmental systems - one that ensures meeting human needs in the long term (World Commission on Environment and Development 1987, Alberti 1996). From the perspective of urban metabolism, a sustainable city is one in which the inflow of material and energy resources and the disposal of waste do not exceed the capacity of the city's surrounding environment (Kennedy et al. 2007). The aim of sustainability is to create the smallest possible ecological footprint and to produce the lowest quantity of pollution possible, to use land efficiently, compost used materials, recycle or convert waste to energy, and to make the city's overall contribution to climate change minimal (McCormick et al. 2013, Yang et al. 2017, Nassauer et al. 2014, Rotmans 2006). As a focus of sustainable development, urban sustainability has become increasingly prominent on political agendas and among scientific studies during recent decades, especially the indicator study that became a pronounced requirement of decision-makers (Huang et al. 2015, Shen et al. 2011, Wu 2014, Valkó et al. 2017). Based on the current study, researchers agree that sustainability depends on social, economic, and environmental factors (INTRASOFT International 2015, Sustainable Cities International 2012, Wu 2014). In the literature, many researchers have begun to explore urban metabolism within the context of urban sustainability (Li et al. 2016, Kennedy et al. 2014) (see Table 2).

Regional Statistics, Vol. 9. No. 1. 2019: 54-71; DOI: 10.15196/RS090103 


\section{Summary of the relationship between urban metabolism indicator sets and urban sustainability}

\begin{tabular}{|c|c|c|c|}
\hline \multirow{2}{*}{$\begin{array}{l}\text { Urban me- } \\
\text { tabolism } \\
\text { indicator set }\end{array}$} & \multicolumn{3}{|c|}{ Urban sustainability factor } \\
\hline & Environmental & Social & Economic \\
\hline $\begin{array}{l}\text { Material flow } \\
\text { analysis }\end{array}$ & $\begin{array}{l}\text { The efficient urban metab- } \\
\text { olism would first result in } \\
\text { the built environment of } \\
\text { the city (Voskamp et al. } \\
2016 \text {, Huang-Hsu 2003, } \\
\text { Kennedy et al. 2014). Re- } \\
\text { source and waste manage- } \\
\text { ment are two key aspects } \\
\text { among the environmental } \\
\text { factors that are also MFA } \\
\text { concerns (INTRASOFT } \\
\text { International 2015, Huang } \\
\text { et al. 2015, Mori- } \\
\text { Christodoulou 2012, } \\
\text { Kennedy et al. 2014). }\end{array}$ & $\begin{array}{l}\text { Li et al. (2016) and Zhang } \\
\text { (2013) use the structural } \\
\text { decomposition of material } \\
\text { flows to build a relation- } \\
\text { ship between input/output } \\
\text { with social wealth, which } \\
\text { can depict the interindustry } \\
\text { relationship of the whole } \\
\text { economy (Szabó 2015). } \\
\text { Dinarès (2014) also pro- } \\
\text { poses social metabolism to } \\
\text { question the apparent } \\
\text { separation between human } \\
\text { beings and their environ- } \\
\text { ment, the society-nature } \\
\text { duality. Barles (2009) and } \\
\text { Broto et al. (2011) attempt } \\
\text { to integrate social aspects } \\
\text { and influences on material } \\
\text { and energy flows. }\end{array}$ & $\begin{array}{l}\text { In the comprehensive } \\
\text { framework for evaluating } \\
\text { sustainability, Ness et al. } \\
\text { (2010) and Li et al. (2016) } \\
\text { implement economy-wide } \\
\text { MFAs based on regional } \\
\text { flows and non-integrated } \\
\text { environmental pressure } \\
\text { indicators. Furthermore, } \\
\text { the decoupling model is a } \\
\text { widely used method to } \\
\text { analyse economic activities } \\
\text { and their dependence on } \\
\text { material consumption } \\
\text { which can be utilized to } \\
\text { build the relation between } \\
\text { urban metabolism and the } \\
\text { economy (Falb-Wolovich } \\
\text { 1967, Li et al. 2016, } \\
\text { Tapio 2005). }\end{array}$ \\
\hline $\begin{array}{l}\text { Emergy } \\
\text { synthesis } \\
\text { analysis }\end{array}$ & $\begin{array}{l}\text { Metabolic flux references } \\
\text { the structure of the meta- } \\
\text { bolic flux in terms of re- } \\
\text { source consumption } \\
\text { (Zhang et al. 2009, Huang- } \\
\text { Hsu 2003). It expresses the } \\
\text { amount of material and } \\
\text { energy from within the } \\
\text { urban metabolic system's } \\
\text { internal environment as } \\
\text { well as from its external } \\
\text { environment. }\end{array}$ & $\begin{array}{l}\text { Yang et al. (2014) and Lei } \\
\text { et al. (2016) indicate that } \\
\text { emergy synthesis can be } \\
\text { adapted to quantify the } \\
\text { flow of resources through } \\
\text { complex ecological- } \\
\text { socioeconomic systems. } \\
\text { The indicator of metabolic } \\
\text { efficiency reflects the re- } \\
\text { source utilization efficiency } \\
\text { (i.e. the economic cost) of } \\
\text { urban development } \\
\text { (Zhang et al. 2009). }\end{array}$ & $\begin{array}{l}\text { Economic metabolic activi- } \\
\text { ties can result in energetic } \\
\text { interactions (Yang et al. } \\
2014, \text { Zhang et al. 2015). } \\
\text { In addition, emergy prod- } \\
\text { ucts are useful to the eco- } \\
\text { nomic system in the form } \\
\text { of fuels, lubricants, and so } \\
\text { on (Ulgiati et al. 1995). }\end{array}$ \\
\hline
\end{tabular}

\section{Conclusion and future directions}

After over 60 years of research, urban metabolism has been advanced as a promising approach for quantifying energy and resource use and supply in modern society. This paper investigates the most relevant urban metabolism mechanisms and indicators for improving urban sustainability. To that end, a literature review of relevant mechanisms and indicators in the field of urban metabolism and sustainability was conducted. The literature selection shows that a sizeable number of studies focus on 
urban metabolism, but only a limited number (23) explore indicators related to sustainability. These studies were reviewed following an adapted version of the CIMOapproach.

In analysing the literature, several findings arise: 1 . most of the study objectives for urban metabolism lie in ecosystem health, energy, environmental technology, urban planning, waste management, and water technology; 2. in these articles, most of the proposed indicators are subject-oriented, which means there is still a lack of systematic indicator frameworks; 3. the most common methods for accounting urban metabolism are MFA and emergy synthesis analysis, which represent two main research streams in urban metabolism studies; 4 . in the outcomes, most case studies do not explore the universal application of their research. The review also shows that there are relationships between urban metabolism and sustainability among environmental, social, and economic factors. Based on the integration of urban metabolism and sustainability, urban metabolism indicators can be used to build a connection between the two. This can provide a promising model for guiding urban development towards sustainability. Take MFA and emergy synthesis analysis as examples, the urban metabolism indicators can reflect urban sustainability in terms of environmental, social, and economic aspects.

The body of knowledge around urban metabolism is still growing. Indicator analysis, as one of the most common ways to assess organisational sustainable performance by municipalities, can collect specific quantitative and qualitative information on cities to enable comparisons of multiple areas (Mapar et al. 2017). Therefore, urban metabolism indicator analysis can be applied as an approach to assess sustainability. Future research directions on urban metabolism indicators could move in the following directions:

1. Quantitative correlation research on urban metabolism indicators with sustainability factors. The amount of the extant research implies the potential for using urban metabolism indicators to assess sustainability, for example, using energy flow accounting to measure urban sustainability (Browne et al. 2012). However, the correlation is not explored yet for all urban metabolism indicators.

2. Develop a standard classification system for stocks and flows, as Kennedy et al. (2011) mentions. Based on the review of urban metabolism literature, we found that the accounting methods and units vary among different studies. The nonstandard classification differences can be a big barrier when comparing urban metabolism among multiple cities/regions.

3. Explore the application in urban design and planning. Several researchers attempt to connect urban metabolism to urban design and planning but most still focus on the process optimisation rather than quantifying resource flows using indicators. However, urban metabolism could be used to develop an approach that informs the design process for sustainability.

Regional Statistics, Vol. 9. No. 1. 2019: 54-71; DOI: 10.15196/RS090103 
4. A comprehensive sustainability-aimed urban metabolism indicator system. To date, there is no comprehensive urban metabolism indicator list. However, an urban metabolism indicator list could be identified after a comprehensive selection by experts. It could be a useful tool for assessing the performance of urban metabolism to measure the shift in urban development towards sustainability.

\section{Acknowledgements}

The funding for this study was provided by the China Scholarship Council (CSC No. 201606260044). We would also like to thank the members of the Horizon 2020 Research and Innovation Action project REPAiR (REsource Management in Periurban Areas: Going Beyond Urban Metabolism) who helped collect the literature material and provided constructive comments.

\section{REFERENCES}

Abbasi, T.-Premalatha, M.-Abbasi, S. A. (2012): Masdar City: A Zero Carbon, Zero Waste Myth Current Science 102(1): 12.

ACebillo, J. (2012): A New Urban Metabolism: Barcelona/Lugano Case Studies. I. CUP, Accademia di architettura, Università della Svizzera Italiana; AB Publishers; Mendrisio, Barcelona, New York.

Alberti, M. (1996): Measuring Urban Sustainability Environmental Impact Assessment Review 16(4-6): 381-424. https://doi.org/10.1016/S0195-9255(96)00083-2

BARLES, S. (2009): Urban Metabolism of Paris and Its Region Journal of Industrial Ecology 13(6): 898-913. https://doi.org/10.1111/j.1530-9290.2009.00169.x.

BENYUS, J. M. (2009): Biomimicry: Innovation Inspired by Nature Harper Collins Publishers, New York. https://www.overdrive.com/search?q=D9D9103D-AD2D-41C4-B95341DC68EF3899.

Broto, V. C.-AlLEN, A.-RAPOPORT, E. (2011): Interdisciplinary Perspectives on Urban Metabolism Journal of Industrial Ecology 16(6): 851-861. https://doi.org/10.1111/j.1530-9290.2012.00556.x

Browne, D.-O’Regan, B.-Moles, R. (2012): Comparison of Energy Flow Accounting, Energy Flow Metabolism Ratio Analysis and Ecological Footprinting as Tools for Measuring Urban Sustainability: A Case-Study of an Irish City-Region Ecological Economics 83: 97-107. https://doi.org/10.1016/j.ecolecon.2012.08.006.

CAprotтt, F. (2014): Critical Research on Eco-Cities? A Walk through the Sino-Singapore Tianjin Eco-City, China Cities 36: 10-17. https://doi.org/10.1016/j.cities.2013.08.005.

Chen, B.-Chen, S. (2014): Eco-Indicators for Urban Metabolism Ecological Indicators 47: 5-6. https://doi.org/10.1016/j.ecolind.2014.09.021.

CHEN, B.-WANG, R. (2014): Integrated Ecological Indicators for Sustainable Urban Ecosystem Evaluation and Management Ecological Indicators 47: 1-4. https://doi.org/10.1016/j.ecolind.2014.09.020.

Regional Statistics, Vol. 9. No. 1. 2019: 54-71; DOI: 10.15196/RS090103 
Chifari, R.-Renner, A.-Lo Piano, S.-Ripa, M.-Bukkens, S. G.F.-Giampietro, M. (2017): Development of a Municipal Solid Waste Management Decision Support Tool for Naples, Italy Journal of Cleaner Production 161: 1032-1043. https://doi.org/10.1016/j.jclepro.2017.06.074.

Chrysoulakis, N.-Lopes, M.-SAn José, R.-Grimmond, C. S. B.-Jones, M. B.Magliulo, V.- Klostermann, J. E. M. (2013): Sustainable Urban Metabolism as a Link between Bio-Physical Sciences and Urban Planning: The BRIDGE Project Landscape and Urban Planning 112(1): 100-117. https://doi.org/10.1016/j.landurbplan.2012.12.005.

Decker, E. H.-ElliotT, S.-Smith, F. A.-Blake, D. R.-Rowland, F. S. (2000): Energy and Material Flow Through the Urban Ecosystem Annual Review of Energy and the Environment 25: 685-740. https://doi.org/10.1146/annurev.energy.25.1.685.

Dempsey, N. (2010): Revisiting the Compact City? Built Environment 36(1): 5-8. https://doi.org/10.2148/benv.36.1.5.

Denyer, D.-Tranfield, D.-VAn AKen, J. E. (2008): Developing Design Propositions through Research Synthesis Organization Studies 29(3): 393-413. https://doi.org/10.1177/0170840607088020.

DiNARÈs, M. (2014): Urban Metabolism: A Review of Recent Literature on the Subject Documents d'analisi Geogräfica 60(3): 551-571. http://dx.doi.org/10.5565/rev/dag.134.

FAinstein, S. S. (2010): The Just City Cornell University Press, Ithaca. https://login.proxy.bib.uottawa.ca/login?url=http://ebookcentral.proquest.com $/$ lib/ottawa/detail.action?docID $=3138037$.

Falb, P. L.-Wolovich, W. A. (1967): Decoupling in the Design and Synthesis of Multivariable Control Systems IEEE Transactions on Automatic Control 12(6): 651-659. https://doi.org/10.1109/TAC.1967.1098737.

Ferrão, P.-FernandeZ, J. E. (2013): Sustainable Urban Metabolism The MIT Press, Cambridge, London. http://site.ebrary.com/id/10752785.

FISCHER-KOWALSKI, M. (2002): Exploring the History of Industrial Metabolism. In: AYRES, R. U.-AYres, L.: A Handbook of Industrial Ecology $1^{\text {st }}$ Edition., pp. 35-45.: Edward Elgar. Cheltenham, Northampton.

GenG, Y.-LiU, Y.-LiU, D.-ZhaO, H.-Xue, B. (2011): Regional Societal and Ecosystem Metabolism Analysis in China: A Multi-Scale Integrated Analysis of Societal Metabolism (MSIASM) Approach Energy 36(8): 4799-4808. https://doi.org/10.1016/j.energy.2011.05.014.

Goldstein, B.-Birkved, M.-Quitzau, M.-B.-Hauschild, M. (2013): Quantification of Urban Metabolism through Coupling with the Life Cycle Assessment Framework: Concept Development and Case Study Environmental Research Letters 8(3): 1-14. https://doi.org/10.1088/1748-9326/8/3/035024.

GonzÁlez, A.-Donnelly, A.-Jones, M.-Chrysoulakis, N.-Lopes, M. (2013): A Decision-Support System for Sustainable Urban Metabolism in Europe Environmental Impact Assessment Review 38: 109-119. https://doi.org/10.1016/j.eiar.2012.06.007.

Regional Statistics, Vol. 9. No. 1. 2019: 54-71; DOI: 10.15196/RS090103 
Hoekman, P.-von BlotTnitz, H. (2017): Cape Town's Metabolism: Insights from a Material Flow Analysis Journal of Industrial Ecology 21(5): 1237-1249.

https://doi.org/10.1111/jiec.12508.

Hoornweg, D. A.-CAmpillo, G.-Linders, D.-Sugar, L.-SAldivar-SAli, A. N. (2012): Mainstreaming Urban Metabolism: Advances and Challenges in City Participation In: World Bank Sixth Urban Research and Knowledge Symposium Rethinking Cities Barcelona.

HuANG, L.-WU, J.-YAN, L. (2015): Defining and Measuring Urban Sustainability: A Review of Indicators Landscape Ecology 30(7): 1175-1193. https://doi.org/10.1007/s10980-015-0208-2.

HuAnG, S-L.-Hsu, W-L. (2003): Materials Flow Analysis and Emergy Evaluation of Taipei's Urban Construction Landscape and Urban Planning 63(2): 61-74. https://doi.org/10.1016/S0169-2046(02)00152-4.

InOstroZA, L. (2014): Measuring Urban Ecosystem Functions through 'Technomass' - A Novel Indicator to Assess Urban Metabolism Ecological Indicators 42: 10-19. https://doi.org/10.1016/j.ecolind.2014.02.035.

INTRASOFT INTERNATIONAL (2015): Science for Environment Policy IN-DEPTH REPORT: Indicators for Sustainable Cities European Commission, Bristol.

https://doi.org/10.2779/61700.

Kennedy, C.-STewart, I. D.-Ibrahim, N.-FACchini, A.-Mele, R. (2014): Developing a Multi-Layered Indicator Set for Urban Metabolism Studies in Megacities Ecological Indicators 47: 7-15. https://doi.org/10.1016/j.ecolind.2014.07.039.

Kennedy, C. A.-Cuddihy, J.-Engel-YAn, J. (2007): The Changing Metabolism of Cities Journal of Industrial Ecology 11(2): 43-59. https://doi.org/10.1162/jie.2007.1107.

Kennedy, C. A.-Hoornweg, D. (2012): Mainstreaming Urban Metabolism Journal of Industrial Ecology 16(6): 780-782. https://doi.org/10.1111/j.1530-9290.2012.00548.x.

Kennedy, C. A.-STewart, I.-FAcchini, A.-Cersosimo, I.-Mele, R.-Chen, B.-UdA, M. (2015): Energy and Material Flows of Megacities Proceedings of the National Academy of Sciences 112(19): 5985-5990. https://doi.org/10.1073/pnas.1504315112.

Kennedy, C.-Pincetl, S.-Bunje, P. (2011): The Study of Urban Metabolism and Its Applications to Urban Planning and Design Environmental Pollution 159(8-9): 1965-1973. https://doi.org/10.1016/j.envpol.2010.10.022.

Kolbadi, N.-Mohammadi, M.-Namvar, F. (2015): Smart Growth Theory as One of the Main Paradigms of Sustainable City International Journal of Review in Life Sciences 5(9): 209-219.

LEI, K.-LiU, L.-Hu, D.-Lou, I. (2016): Mass, Energy, and Emergy Analysis of the Metabolism of Macao Journal of Cleaner Production 114: 160-170. https://doi.org/10.1016/j.jclepro.2015.05.099.

Li, Y.-Beeton, R. J. S.-Halog, A.-Sigler, T. (2016): Evaluating Urban Sustainability Potential Based on Material Flow Analysis of Inputs and Outputs: A Case Study in Jinchang City, China Resources, Conservation and Recycling 110: 87-98. https://doi.org/10.1016/j.resconrec.2016.03.023.

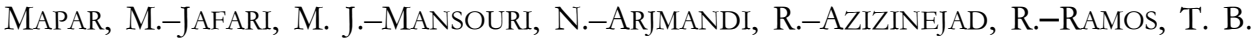
(2017): Sustainability Indicators for Municipalities of Megacities: Integrating

Regional Statistics, Vol. 9. No. 1. 2019: 54-71; DOI: 10.15196/RS090103 
Health, Safety and Environmental Performance Ecological Indicators 83: 271-291. https://doi.org/10.1016/j.ecolind.2017.08.012.

McCormick, K.-Anderberg, S.-Coenen, L.-NeiJ, L. (2013): Advancing Sustainable Urban Transformation Journal of Cleaner Production 50: 1-11. https://doi.org/10.1016/j.jclepro.2013.01.003.

McDonough, W.-Braungart, M. (2002): Cradle to Cradle: Remaking the Way We Make Things. $1^{\text {st }}$ Edition. North Point Press., New York.

Mori, K.-Christodoulou, A. (2012): Review of Sustainability Indices and Indicators: Towards a New City Sustainability Index (CSI) Environmental Impact Assessment Review 32(1): 94-106. https://doi.org/10.1016/j.eiar.2011.06.001.

Nassauer, J. I.-WU, J.-XIANG, W.-N. (2014): Actionable Urban Ecology in China and the World: Integrating Ecology and Planning for Sustainable Cities Landscape and Urban Planning 125: 207-208.

https://doi.org/10.1016/j.landurbplan.2014.02.022.

Ness, B.-Anderberg, S.-Olsson, L. (2010): Structuring Problems in Sustainability Science: The Multi-Level DPSIR Framework Geoforum 41(3): 479-488. https://doi.org/10.1016/j.geoforum.2009.12.005.

Richards, D. J.-Allenby, B. R.-Frosch, R. A. (1994): The Greening of Industrial Ecosystems: Overview and Perspective In: Allenby, B. R.-Richards, D. J The Greening of Industrial Ecosystems pp. 1-19. The National Academy Press, Washington D.C. https://doi.org/10.17226/2129.

Rosado, L.-Kalmykova, Y.-Patrício, J. (2016): Urban Metabolism Profiles. An Empirical Analysis of the Material Flow Characteristics of Three Metropolitan Areas in Sweden Journal of Cleaner Production 126: 206-217. https://doi.org/10.1016/j.jclepro.2016.02.139.

RotMAns, J. (2006): Tools for Integrated Sustainability Assessment: A Two-Track Approach The Integrated Assessment Journal 6(4): 35-57.

SHEN, L.-Y.-OchOA, J. J.-ShAH, M. N.-ZhAnG, X. (2011): The Application of Urban Sustainability Indicators - A Comparison between Various Practices Habitat International 35(1): 17-29. https://doi.org/10.1016/j.habitatint.2010.03.006.

Soria-LarA, J. A.-Bertolini, L.-TE BrÖmmelstroet, M. (2016): Towards a More Effective EIA in Transport Planning: A Literature Review to Derive Interventions and Mechanisms to Improve Knowledge Integration Journal of Environmental Planning and Management 60(5): 755-772. https://doi.org/10.1080/09640568.2016.1180282.

Straatemeier, T.-Bertolini, L.-Te Brömmelstroet, M.-Hoetjes, P. (2010): An Experiential Approach to Research in Planning Environment and Planning B: Planning and Design 37(4): 578-591. https://doi.org/10.1068/b35122.

Sun, L.-Li, H.-DONG, L.-FANG, K.-REN, J.-GENG, Y.-FujII, M.-ZHANG, W.-ZHANG, N.-LIU, Z. (2017): Eco-Benefits Assessment on Urban Industrial Symbiosis Based on Material Flows Analysis and Emergy Evaluation Approach: A Case of Liuzhou City, China Resources, Conservation and Recycling 119: 78-88. https://doi.org/10.1016/j.resconrec.2016.06.007.

Regional Statistics, Vol. 9. No. 1. 2019: 54-71; DOI: 10.15196/RS090103 
Sustainable Cities International (2012): Indicators for Sustainability: How Cities Are Monitoring and Evaluating Their Success Vancouver, Canada. www.cashewstory.com.

SzABÓ, N. (2015): Methods for Regionalizing Input-Output Tables Regional Statistics 5(1): 44-65. https://doi.org/10.15196/RS05103.

TAPIO, P. (2005): Towards a Theory of Decoupling: Degrees of Decoupling in the EU and the Case of Road Traffic in Finland between 1970 and 2001 Transport Policy 12(2): 137-151. https://doi.org/10.1016/j.tranpol.2005.01.001.

Townsend, A. M. (2013): Smart Cities: Big Data, Civic Hackers, and the Quest for a New Utopia W. W. Norton \& Company, Inc., New York.

Ulgiati, S.-Brown, M. T.-Bastianoni, S.-Marchettini, N. (1995): Emergy-Based Indices and Ratios to Evaluate the Sustainable Use of Resources Ecological Engineering 5(4): 519-531. https://doi.org/10.1016/0925-8574(95)00043-7.

VAlKó, G.-FeKETE-FARKAS, M.-KovÁCS, I. (2017): Indicators for the Economic Dimension of Sustainable Agriculture in the European Union Regional Statistics 7(1): 179-196. https://doi.org/10.15196/RS07110.

VAn Timmeren, A. (2013): Reciprocities: A Dynamic Equilibrium. $2^{\text {nd }}$ Edition. Delft University of Technology, Delft. https://doi.org/10.13140/2.1.3708.0964.

VAN TIMmeren, A.-HenriQueZ, L.-REYNOLDS, A. (2015): Ubikquity and the Illuminated City. $2^{\text {nd }}$ Edition. TU Delft Publication, Delft.

Voskamp, I. M.-Stremke, S.-Spiller, M.-Perrotti, D.-VAn Der Hoek, J. P. -RijnaARTs, H. H M. (2016): Enhanced Performance of the Eurostat Method for Comprehensive Assessment of Urban Metabolism: A Material Flow Analysis of Amsterdam Journal of Industrial Ecology 21(4): 887-902. https://doi.org/10.1111/jiec.12461.

WeI, H. (2011): Strategy of Urban Transformation in China Journal of Urban and Regional Planning 1: 3.

Wolman, A. (1965): The Metabolism of Cities Scientific American 213(3): 179-190. https://doi.org/10.1038/scientificamerican0965-178.

World COMmission ON ENVIRONMENT AND DEVElopment (1987): Our Common Future Oxford University Press, Oxford, New York.

Wu, J. (2014): Urban Ecology and Sustainability: The State-of-the-Science and Future Directions Landscape and Urban Planning 125: 209-221. https://doi.org/10.1016/j.landurbplan.2014.01.018.

YANG, B.-XU, T.-SHI, L. (2017): Analysis on Sustainable Urban Development Levels and Trends in China's Cities Journal of Cleaner Production 141: 868-880. https://doi.org/10.1016/j.jclepro.2016.09.121.

YANG, D.-GAO, L.-XIAO, L.-WANG, R. (2012): Cross-Boundary Environmental Effects of Urban Household Metabolism Based on an Urban Spatial Conceptual Framework: A Comparative Case of Xiamen Journal of Cleaner Production 27: 1-10. https://doi.org/10.1016/j.jclepro.2011.12.033.

YANG, D.-KAO, W. T. M.-ZHANG, G.-ZHANG, N. (2014): Evaluating Spatiotemporal Differences and Sustainability of Xiamen Urban Metabolism Using Emergy Synthesis Ecological Modelling 272: 40-48. https://doi.org/10.1016/j.ecolmodel.2013.09.014.

Regional Statistics, Vol. 9. No. 1. 2019: 54-71; DOI: 10.15196/RS090103 
A literature review and categorisation of sustainability-aimed urban metabolism indicators: a context, indicator, mechanism, outcome analysis

Zhai, M.-HuAng, G.-LIU, L.-Su, S. (2018): Dynamic Input-Output Analysis for Energy Metabolism System in the Province of Guangdong, China Journal of Cleaner Production 196: 747-762. https://doi.org/10.1016/j.jclepro.2018.06.084.

ZHANG, Y. (2013): Urban Metabolism: A Review of Research Methodologies Environmental Pollution 178: 463-473. https://doi.org/10.1016/j.envpol.2013.03.052.

ZHANG, Y.-LiU, H.-CHEN, B. (2013): Comprehensive Evaluation of the Structural Characteristics of an Urban Metabolic System: Model Development and a Case Study of Beijing Ecological Modelling 252: 106-113.

https://doi.org/10.1016/j.ecolmodel.2012.08.017.

ZHANG, Y.-YANG, Z.-YU, X. (2009): Evaluation of Urban Metabolism Based on Emergy Synthesis: A Case Study for Beijing (China) Ecological Modelling 220: 1690-1696. https://doi.org/10.1016/j.ecolmodel.2009.04.002.

ZHANG, Y.-YANG, Z.-YU, X. (2015): Urban Metabolism: A Review of Current Knowledge and Directions for Future Study Environmental Science and Technology 49(19): 11247-11263. https://doi.org/10.1021/acs.est.5b03060.

Regional Statistics, Vol. 9. No. 1. 2019: 54-71; DOI: 10.15196/RS090103 